\title{
The Prognostic Value of the Immunohistochemical Expression of Phosphorylated RB and p16 Proteins in Association with Cyclin D1 and the p53 Pathway in a Large Cohort of Patients with Breast Cancer Treated with Taxane-based Adjuvant Chemotherapy
}

\author{
THEOFANI GAVRESSEA ${ }^{1}$, KONSTANTINE T. KALOGERAS ${ }^{2,3}$, GEORGIA-ANGELIKI KOLIOU ${ }^{4}$, \\ FLORA ZAGOURI ${ }^{5}$, GEORGIOS LAZARIDIS ${ }^{6}$, HELEN GOGAS $^{7}$, KOSTAS TSIGARIDAS $^{8}$, \\ ANGELOS KOUTRAS ${ }^{9}$, KALLIOPI PETRAKI ${ }^{10}$, CHRISTOS MARKOPOULOS ${ }^{11}$, ELISSAVET PAZARLI ${ }^{12}$, \\ GERASIMOS ARAVANTINOS ${ }^{13}$, CHRISTOS PAPADIMITRIOU ${ }^{5}$, PAVLOS PAPAKOSTAS ${ }^{14}$, \\ NEKTARIOS KOUFOPOULOS ${ }^{15}$, CHARISIOS KARANIKIOTIS $^{16}$, SOFIA CHRISAFI ${ }^{2}$, \\ HARALAMBOS P. KALOFONOS ${ }^{9}$, DIMITRIOS PECTASIDES ${ }^{17}$, \\ GEORGE FOUNTZILAS $^{2,18}$ and KITTY PAVLAKIS ${ }^{19}$ \\ ${ }^{1}$ Department of Pathology, Iaso Women's Hospital, Athens, Greece; \\ ${ }^{2}$ Laboratory of Molecular Oncology, Hellenic Foundation for Cancer Research/ \\ Aristotle University of Thessaloniki, Thessaloniki, Greece; \\ ${ }^{3}$ Translational Research Section, and ${ }^{4}$ Section of Biostatistics, \\ Hellenic Cooperative Oncology Group, Data Office, Athens, Greece; \\ ${ }^{5}$ Department of Clinical Therapeutics, Alexandra Hospital, \\ National and Kapodistrian University of Athens School of Medicine, Athens, Greece; \\ Departments of ${ }^{6}$ Medical Oncology, and ${ }^{12}$ Pathology, Papageorgiou Hospital, \\ Aristotle University of Thessaloniki, School of Health Sciences, Faculty of Medicine, Thessaloniki, Greece; \\ ${ }^{7}$ First Department of Medicine, and ${ }^{11}$ Second Department of Propedeutic Surgery, \\ Laiko General Hospital, National and Kapodistrian University of Athens School of Medicine, Athens, Greece; \\ ${ }^{8}$ First Department of Medical Oncology, Metropolitan Hospital, Piraeus, Greece; \\ ${ }^{9}$ Division of Oncology, Department of Medicine, University Hospital, \\ University of Patras Medical School, Patras, Greece; \\ ${ }^{10}$ Pathology Department, Metropolitan Hospital, Piraeus, Greece; \\ ${ }^{13}$ Second Department of Medical Oncology, Agii Anargiri Cancer Hospital, Athens, Greece; \\ ${ }^{14}$ Oncology Unit, and ${ }^{17}$ Oncology Section, Second Department of Internal Medicine, \\ Hippokration Hospital, Athens, Greece; \\ ${ }^{15}$ Pathology Department, Saint Savvas Anticancer Hospital, Athens, Greece; \\ ${ }^{16}$ Department of Medical Oncology, 424 Army General Hospital, Thessaloniki, Greece; \\ ${ }^{18}$ Aristotle University of Thessaloniki, Thessaloniki, Greece; \\ ${ }^{19}$ Pathology Department, National and Kapodistrian University of Athens Medical School, Athens, Greece
}

\begin{abstract}
Background: The retinoblastoma $(R B)$ gene is a tumor-suppressor gene that plays a central role in

Correspondence to: Theofani Gavressea, MD, Department of Pathology, Iaso Women's Hospital, 37-39 Kifisias Avenue, 15123 Athens, Greece. Mobile: +30 6946114536, Fax: +30 2106185294, e-mail: fanigav@gmail.com
\end{abstract}

Key Words: pRB, p16, breast cancer, immunohistochemistry, chemotherapeutic agents. regulating the cell cycle. Inactivation of this gene is involved in breast cancer. Patients and Methods: A total of 827 patients with breast cancer treated with taxane-based adjuvant chemotherapy were included in the study. Protein expression of $R B$, phosphorylated $R B(p R B), p 16$, cyclin D1 and 553 was evaluated by immunohistochemistry. Results: Neither of the retinoblastoma markers ( $R B$ and $p R B)$ reached statistical significance in terms of their association with disease-free or overall survival. Nevertheless, when clustering analysis was performed, patients with tumors featuring low levels of p16, cyclin D1 and p53 with 
concomitantly high levels of $p R B$ had reduced risk for relapse (Wald's $p=0.015$ ). Conclusion: The p53-mediated sensitivity of breast cancer cells to chemotherapeutic agents appears to be driven mostly by $p R B$. Using agents that enhance $R B$ phosphorylation might possibly increase the chemosensitivity of breast cancer cells.

Breast cancer is the second most frequent type of cancer worldwide and the most prevalent in women. In spite of the great progress that has been achieved in the understanding of the molecular basis of the disease, as well as a considerable improvement in treatment modalities, a remarkable number of tumors will still recur and metastasize $(1,2)$. During the past years, most research on the biological behavior of breast cancer cells has been focused on the alterations of several regulatory pathways that might influence their sensitivity to therapeutic agents (3-5).

One of the most thoroughly studied pathways is the p53 regulatory pathway. In spite of the fact that it is disrupted in more than $50 \%$ of human tumors, most clinical studies have failed to correlate the status of p53 with the outcome of patients (6). It has been demonstrated that mutations in $p 53$ or loss of p53 function are associated with multidrug resistance in many tumors (7). Moreover, it was recently shown that p53 may act both as an effector and as an inhibitor of dose-dense chemotherapy depending on the type of tumor under treatment (8). It is clear that the reasons, not only for the specific properties of each different type of tumor population, but also regarding the changes of the factors that interfere with the downstream regulation of the activated p53 pathway should be sought.

One of the key modulators, downstream of the p53 pathway, is the retinoblastoma $(R B)$ gene (9). This tumorsuppressor gene encodes a nuclear phosphoprotein that plays a central role in regulating the cell cycle. Inactivation of both alleles of this gene is involved in retinoblastoma, which is a rare childhood malignancy. $R B$ loss is also a well-characterized occurrence in many human cancer types, propably through a disruption of the p16/RB pathway (10). Lee et al. were the first to highlight the inactivation of the $R B$ gene in breast cancer (11). Events that can lead to a disrupted RB pathway comprise of p16 loss, cyclin D1 amplification or overexpression and loss of heterozygosity, although the latter is not always associated with low protein expression of RB (10). Regarding p16 protein expression, it appears that nuclear 16 expression more accurately reflects p16 biological function, despite the fact that some investigators also took into account the cytoplasmic expression of p16 (12). While there are different hypotheses that explain the presence of p16 protein in the cytoplasm, the action of the p16 protein that leads to phosphorylation of the RB protein is an event which takes place inside the nucleus (10).
In patients with breast cancer, the presence of a normal or disrupted RB pathway seems to determine the p53-mediated response to chemotherapeutic agents (5). Specifically, $R B$ silencing or hyper-phosphorylation reduces the prognostic role of p53 status, as far as the clinical outcome of the patients is concerned. Since RB phosphorylation is induced by cyclin-dependent-kinases, such as cyclin D1, while it is hindered by cyclin-dependent-kinase inhibitors, such as p16 (INK4A) (10), the study of the interaction of the above molecules would probably highlight the several steps that interfere with the protective role of the p53 pathway in patients with breast cancer.

In the present study, we sought to determine the immunohistochemical expression of RB, phosphorylated RB $(\mathrm{pRB})$ and $\mathrm{p} 16$ in a large series of patients with breast cancer treated with adjuvant taxane-based chemotherapy and relate our results to several clinicopathological parameters, as well as to the clinical outcome of the patients. Our goal was to evaluate their possible prognostic/predictive value, as well as their interaction with the expression of the cyclin D1 and p53 proteins.

\section{Patients and Methods}

Patient population. This was a retrospective translational research study of 1,086 adjuvant patients with breast cancer enrolled in a prospective phase III trial. The HE10/00 trial $(2,13)$ was a randomized phase III trial (ACTRN12609001036202) on patients with intermediate/high-risk operable breast cancer, comparing four cycles of epirubicin followed by three cycles of paclitaxel (Taxol®, Bristol Myers-Squibb, Princeton, NJ, USA) followed by three cycles of the intensified cyclophosphamide/methotrexate/5fluorouracil regimen (E-T-CMF) given every 2 weeks with four cycles of epirubicin/paclitaxel combination (given on the same day) every 3 weeks followed by three cycles of intensified CMF every 2 weeks. By study design, the cumulative doses and the chemotherapy duration were identical in the two arms but dose intensity of epirubicin and paclitaxel was double in the E-T-CMF arm. The current definition of high-risk breast cancer is based on the International Expert Consensus on the Primary Therapy of Early Breast Cancer 2007 (14). Specifically, high-risk patients were node-positive patients with 1-3 involved lymph nodes and absence of estrogen receptor (ER) and progesterone receptor (PgR), or epidermal growth factor receptor 2 (HER2) gene overexpressed or amplified; or node-positive patients with four or more involved lymph nodes. A total of 1,086 eligible patients with node-positive operable breast cancer were accrued in a period of 5 years (2000-2005).

HER2-positive patients received trastuzumab upon relapse, as previously described (15); no anti-HER2 treatment was given in the adjuvant setting. Treatment schedules and eligibility criteria for the clinical trial have been made publicly available at: http://hecogimages.gr/HECOG-TRIALS/HE1000_TREATMENT

Baseline characteristics and clinical outcomes of the trial have already been described $(2,13,16)$. Primary tumor diameter, axillary nodal status and tumor grade were obtained from the pathology report. Clinical protocols were approved by local regulatory 
authorities, while the present translational research study was approved by the Papageorgiou Hospital Institutional Review Board (July 15, 2013) and the Bioethics Committee of the Aristotle University of Thessaloniki School of Medicine (December 18, 2013). All patients signed a study-specific written informed consent before randomization, which in addition to giving consent for the trial allowed the use of biological material for future research purposes. All clinical investigations related to the present study have been conducted according to the principles expressed in the Declaration of Helsinki.

Tissue microarray (TMA) construction. Formalin-fixed paraffinembedded (FFPE) tumor tissue samples from 857 patients $(79.0 \%$ of 1,086 randomized patients) were prospectively collected from the trial. Of these, 30 cases were excluded due to inadequate FFPE tumor tissue, thus reducing the number of eligible/evaluable patients to 827. The REMARK diagram (17) for the study is shown in Figure 1. Hematoxylin-eosin stained sections from the tissue blocks were reviewed by two experienced breast cancer pathologists and the most representative tumor areas were marked for the construction of the TMA blocks with the use of a manual arrayer (Model I; Beecher Instruments, San Prairie, WI, USA), as previously described $(18,19)$. Each case was represented by two tissue cores, $1.5 \mathrm{~mm}$ in diameter, obtained from the most representative areas of primary invasive tumors, or in some cases (9.6\%) from synchronous axillary lymph node metastases, and reembedded in 35 microarray blocks. Each TMA block contained 38 to 66 tissue cores from the original tumor tissue blocks, while cores from various neoplastic, non-neoplastic and reactive tissues were also included, serving as orientation controls for slide-based assays. Cases not represented, damaged or inadequate on the TMA sections were re-cut from the original blocks, when material was available, and these sections were used for protein expression analysis.

Immunohistochemistry (IHC). IHC labeling was performed according to standard protocols on serial $2.5 \mu \mathrm{m}$-thick sections from the original blocks or the TMA blocks. In order to ensure optimal reactivity, immunostaining was applied 7 to 10 days after sectioning at the Laboratory of Molecular Oncology of the Hellenic Foundation for Cancer Research, Aristotle University of Thessaloniki School of Medicine. The staining procedures for ER (clone 6F11, dilution 1:70; Novocastra ${ }^{\mathrm{TM}}$, Leica Biosystems, Newcastle, UK), PgR (clone 1A6, dilution 1:70; Novocastra ${ }^{\mathrm{TM}}$, Leica Biosystems), HER2 (A0485 polyclonal antibody, dilution 1:200; Dako, Glostrup, Denmark), Ki67 (clone MIB-1, dilution 1:70; Dako), epidermal growth factor receptor (EGFR, clone 31G7, dilution 1:50; Invitrogen, Carlsbad, MA, USA), cytokeratin 5 (CK5, clone XM26, dilution 1:50; Novocastra ${ }^{\mathrm{TM}}$, Leica Biosystems), RB (mouse mAb, clone 4H1, dilution 1:100; Cell Signaling Technology, Essex, MA, USA), pRB (rabbit pAb, clone S608, dilution 1:100; Cell Signaling Technology), p16 (clone E6H4 ready to use; CINtec Histology, Mtm Laboratories AG, Heidelberg, Germany), cyclin D1 (clone SP4, dilution 1:200; Spring Biosciences, Fremont, CA, USA) and p53 (clone DO-7, dilution 1:100; Dako) were performed using Dako and Bond $\mathrm{Max}^{\mathrm{TM}}$ autostainers (Leica Microsystems, Wetzlar, Germany), as previously described in detail (20-24).

Interpretation of the IHC results. The evaluation of all IHC sections was carried out by two experienced breast cancer pathologists, blinded as to the patients' clinical characteristics and survival data, according

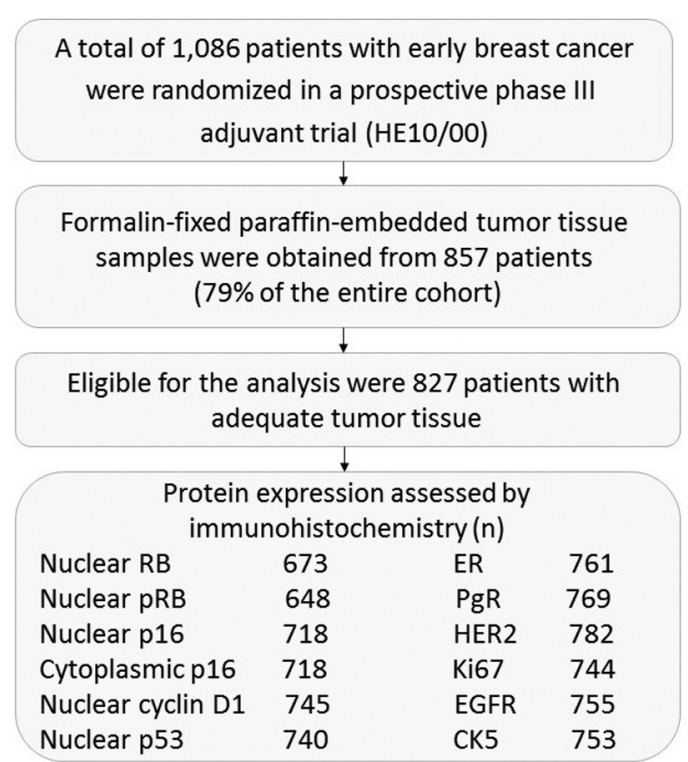

Figure 1. REMARK diagram. RB: Retinoblastoma; $p R B$ : phosphorylated $R B$; ER: estrogen receptor; PgR: progesterone receptor; HER2: epidermal growth factor receptor 2; EGFR: epidermal growth factor receptor; CK5: cytokeratin 5.

to existing established criteria, as previously described (15). Briefly, ER and $\mathrm{PgR}$ were considered positive if staining was present in $\geq 1 \%$ of tumor cell nuclei (25). HER2 protein expression was scored on a scale from 0 to $3+$, the latter corresponding to uniform, intense membranous staining in $>30 \%$ of invasive tumor cells (26). For Ki67, the expression was defined as low $(<20 \%)$ or high $(\geq 20 \%)$ based on the percentage of stained nuclei from the tumor areas (27). For EGFR, membranous protein expression was scored on a scale from 0 to $3+$, with any staining in $\geq 1 \%$ of tumor cells being considered positive (18). CK5 cytoplasmic staining was considered to be positive if any specific staining was observed (28). For RB protein expression, we evaluated the intensity of the nuclear stain, scored as 0: absent, 1: low, 2: intermediate and 3: strong. Any intensity (scores 1, 2 or 3) was considered to be positive RB expression (10). For pRB protein expression, the percentage of stained nuclei was recorded and a cutoff of $\geq 25 \%$ was used for positivity (9). Representitive images of staining for RB and $\mathrm{pRB}$ are presented in Figure 2. The concurrent expression of RB and pRB was also examined, with absence of RB expression or high expression of $\mathrm{pRB}(\geq 25 \%)$ demonstrating an altered or disrupted RB pathway, while positive RB expression with concomitant low expression of pRB $(<25 \%)$ was considered to indicate a normal RB pathway (9).p16 staining was scored for nuclear and cytoplasmic protein expression on a scale of 0-3 based on the percentage of positive cells ( 0 : no staining, $1:<25 \%, 2: 25-75 \%$ and 3: $>75 \%$ ), with low p16 protein expression referring to scores 0 and 1 and high p16 referring to scores 2 and 3 (29). Cyclin D1 was evaluated for nuclear intensity, scored as 0: absent, 1: low, 2: intermediate and 3: strong (30). p53 protein expression was evaluated using a cut-off value of $\geq 10 \%$ of stained nuclei, indicating high expression (9). Representitive images of staining for nuclear and cytoplasmic p16, cyclin D1 and p53 are presented in Figure 3. 

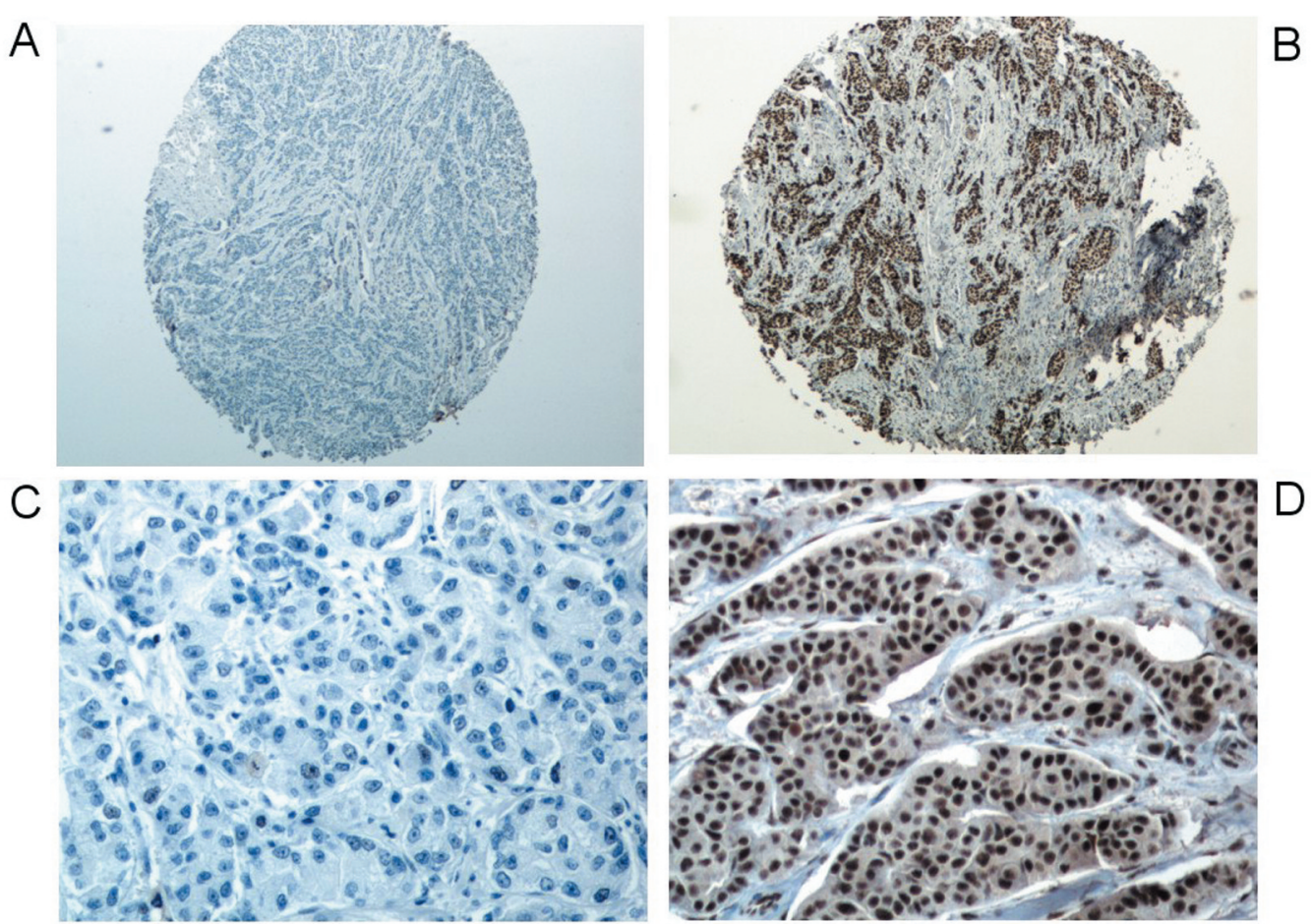

Figure 2. Representative staining images for retinoblastoma $(R B)$ and phosphorylated $R B(p R B)$. Absence (A) and high (B) nuclear expression of the RB protein $(\times 40$ magnification). Low $(C)$ and high $(D)$ nuclear expression of the pRB protein $(\times 200$ magnification).
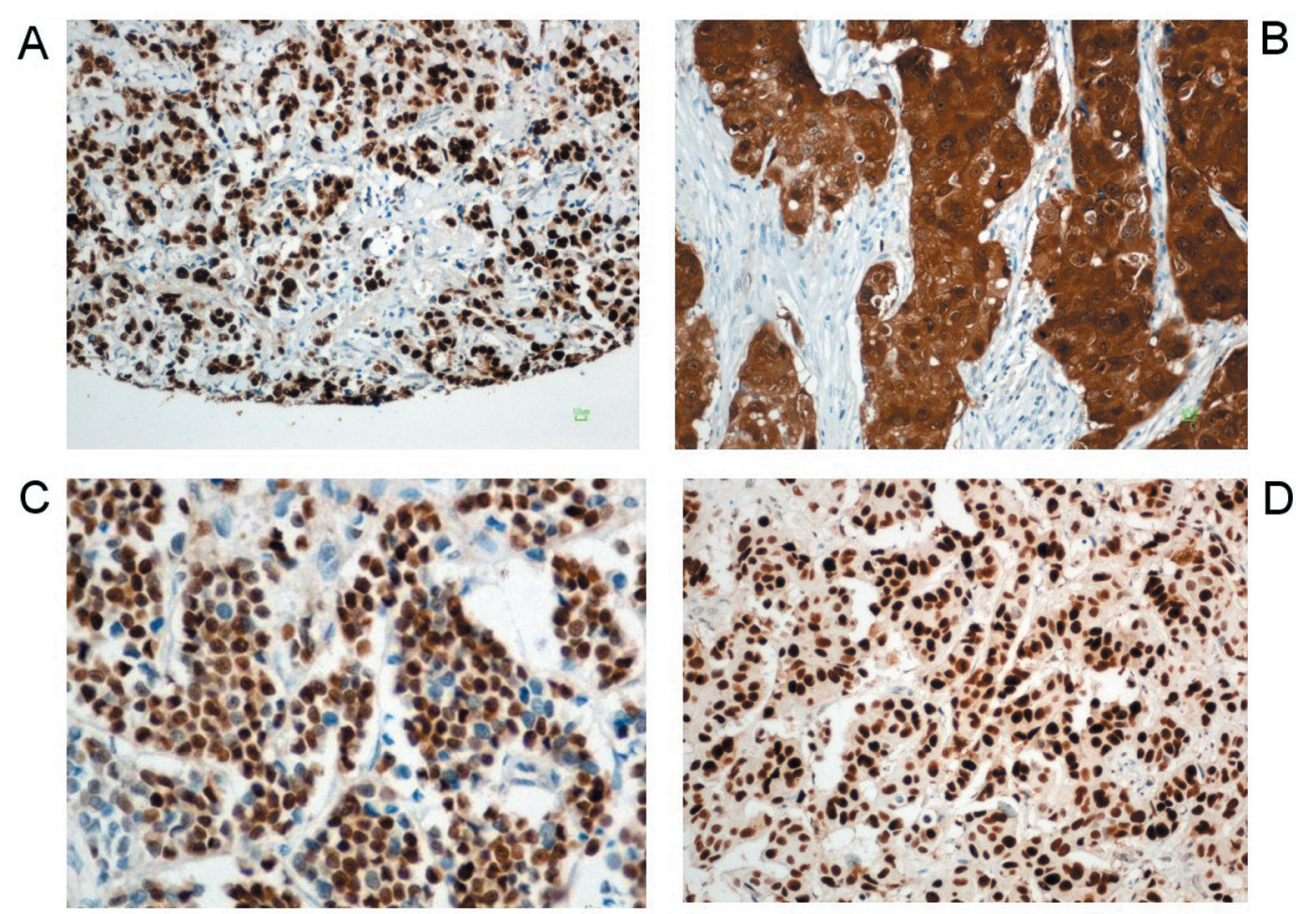

Figure 3. Representitive staining images for nuclear and cytoplasmic p16, cyclin D1 and p53. High nuclear (A) and cytoplasmic (B) p16 protein expression ( $\times 200$ magnification). Strong cyclin D1 (C) and high p53 (D) nuclear protein expression ( $\times 200$ magnification). 


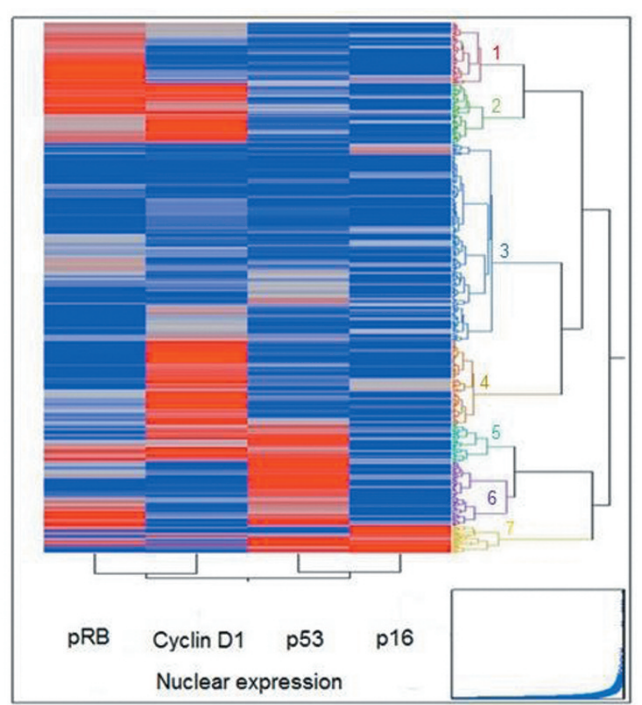

Figure 4. Dendrogram of the initial clustering scheme. Seven clusters were identified based on nuclear phosphorylated $R B(p R B)$, cyclin D1, p53 and p16 protein expression.

If one of the tissue cores was lost or damaged the overall score was determined from the remaining one. When whole tissue sections were used, the entire tumor area was evaluated. The evaluation of ER, PgR, HER2, Ki67, EGFR and CK5 was performed in order to categorize our patients into immunohistochemically defined subtypes.

Fluorescence in situ hybridization (FISH). TMA sections or whole tissue sections ( $5 \mu \mathrm{m}$-thick) were used for FISH analysis, using the ZytoLight ${ }^{\circledR}$ SPEC HER2/TOP2A/CEP17 triple-color probe (Z-2073; ZytoVision, Bremerhaven, Germany), as previously described (31). FISH was performed according to the manufacturer's protocol with minor modifications in all cases, not only the HER2 IHC $2+$ cases.

Digital images were constructed using specifically developed software for cytogenetics (XCyto-Gen; ALPHELYS, Plaisir, France). Processed sections were considered eligible for FISH evaluation according to the ASCO/CAP criteria (26). For the evaluation of the HER2 gene status, non-overlapping nuclei from the invasive part of the tumor were randomly selected, according to morphological criteria using 4, 6-diamidino-2-phenylindole staining, and scored. Twenty tumor nuclei were counted according to Press et al. (32). The HER2 gene was considered to be amplified when the HER2/CEP17 ratio was $>2.2$ (26), or the mean HER2 copy number was $>6$ (33). In cases with values at or near the cut-off (i.e. 1.8-2.2), 20-40 additional nuclei were counted and the ratio was recalculated. In cases with ratios that were still borderline, additional FISH assays were performed on whole sections (34). The data from the evaluation of TOP $2 A$ gene status are neither analyzed nor presented here.

Statistical methods. Disease-free survival (DFS) was defined as time from study entry to first tumor recurrence, secondary neoplasm, or death from any cause, while overall survival (OS) was also measured from study entry until death from any cause (35). Surviving patients were censored at the date of last contact. Timeto-event distributions were estimated using Kaplan-Meier curves

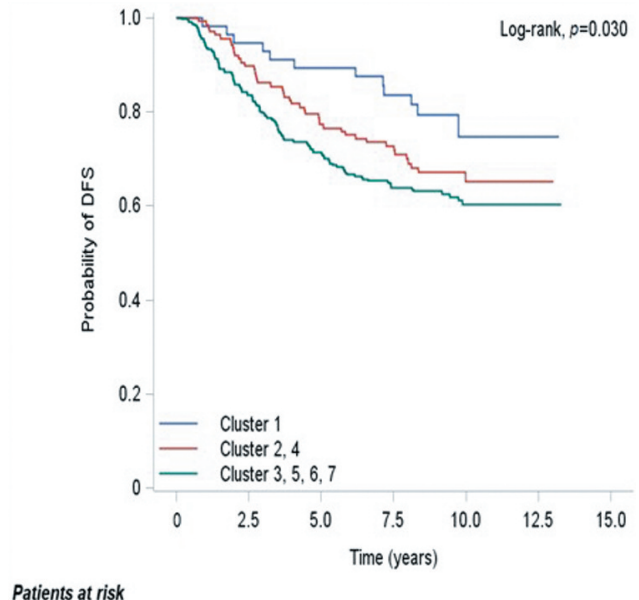

\begin{tabular}{|c|c|c|c|}
\hline \multicolumn{4}{|l|}{ Patients at risk } \\
\hline Cluster $1 \quad 59$ & 50 & 13 & 0 \\
\hline Cluster 2,4 139 & 104 & 35 & 0 \\
\hline Cluster $3,5,6,7 \quad 315$ & 217 & 72 & 0 \\
\hline
\end{tabular}

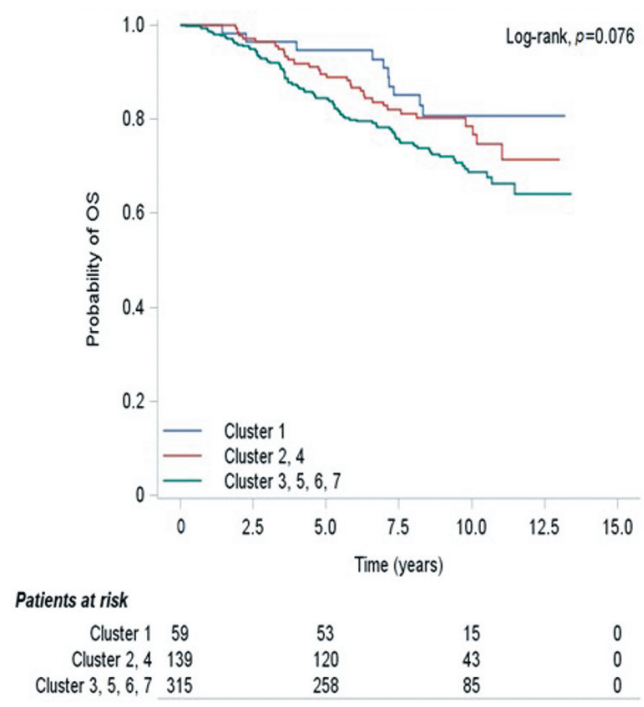

Figure 5. Kaplan-Meier curves for the grouped scheme in terms of (A) disease-free survival (DFS) and (B) overall survival (OS).

and compared using log-rank tests. Univariate Cox regression was used to examine the prognostic significance of $\mathrm{RB}, \mathrm{pRB}, \mathrm{RB}$ pathway function, p16 nuclear and p16 cytoplasmic expression (using the cut-offs described above) with regard to DFS and OS.

Further exploratory analysis was conducted using unsupervised hierarchical clustering with Ward's minimum variance method in order to identify distinct groups (clusters). The optimal number of clusters was selected by the use of pseudo F-statistics and correlation with DFS. In order to assess the accuracy of the statistically significant clustering results, an internal validity method was used. One hundred random samples, each consisting of $70 \%$ of the cases with clustering results, were selected and univariate Cox regression analysis was applied to each of them. Significance in 
Table I. Patient and tumor characteristics.

\begin{tabular}{|c|c|c|}
\hline Characteristic & \multicolumn{2}{|c|}{ Value } \\
\hline \multicolumn{3}{|l|}{ Age } \\
\hline Median (range), years & \multicolumn{2}{|c|}{$53.5(22.4-79.3)$} \\
\hline$\leq 53$ Years, $\mathrm{n}(\%)$ & 404 & 48.9 \\
\hline$>53$ Years, $\mathrm{n}(\%)$ & 423 & 51.2 \\
\hline \multicolumn{3}{|l|}{ Menopausal status, n (\%) } \\
\hline Premenopausal & 366 & 44.2 \\
\hline Postmenopausal & 461 & 55.8 \\
\hline \multicolumn{3}{|l|}{ Tumor size } \\
\hline Median (range) & \multicolumn{2}{|c|}{$2.7(0.19-15.0)$} \\
\hline$\leq 2 \mathrm{~cm}, \mathrm{n}(\%)$ & 249 & 30.2 \\
\hline$>2 \mathrm{~cm}, \mathrm{n}(\%)$ & 577 & 69.8 \\
\hline Unknown & 1 & 0.1 \\
\hline \multicolumn{3}{|l|}{ Histological type, n (\%) } \\
\hline Invasive ductal & 652 & 78.8 \\
\hline Invasive lobular & 77 & 9.4 \\
\hline Mixed & 50 & 6.0 \\
\hline Other & 48 & 5.8 \\
\hline \multicolumn{3}{|l|}{ Histological grade, $\mathrm{n}(\%)$} \\
\hline I & 47 & 5.6 \\
\hline II & 371 & 44.8 \\
\hline III & 409 & 49.4 \\
\hline \multicolumn{3}{|l|}{ Positive lymph nodes, $\mathrm{n}(\%)$} \\
\hline $0-3$ & 390 & 47.2 \\
\hline$\geq 4$ & 436 & 52.8 \\
\hline Unknown & 1 & 0.1 \\
\hline \multicolumn{3}{|l|}{ Surgery, n (\%) } \\
\hline Breast-conserving & 280 & 33.8 \\
\hline Modified radical mastectomy & 547 & 66.2 \\
\hline \multicolumn{3}{|l|}{ ER/PgR status, $\mathrm{n}(\%)$} \\
\hline Positive & 595 & 72.0 \\
\hline Negative & 172 & 20.8 \\
\hline Unknown & 60 & 7.2 \\
\hline \multicolumn{3}{|l|}{ HER2 status, n (\%) } \\
\hline Positive & 101 & 12.2 \\
\hline Negative & 681 & 82.4 \\
\hline
\end{tabular}

terms of DFS was observed in 21 samples and a trend in 28 , while the corresponding numbers for OS were 9 and 14.

The role of the examined markers and the clustering schemes that reached significance in the univariate analysis was assessed in multivariate Cox regression analyses using a backward selection procedure with a removal criterion of $p>0.15$. Variable selection was based on the likelihood ratio test, including the following factors as confounders: menopausal status (premenopausal vs. postmenopausal), nodal status ( $0-3 v s . \geq 4$ positive lymph nodes), tumor size ( $>2 v s . \leq 2 \mathrm{~cm}$ ), radiotherapy (yes $v s$. no), hormonal therapy (yes $v s$. no), type of operation (modified radical mastectomy $v s$. breast-conserving surgery) and subtypes (luminal B, luminalHER2, HER2-enriched, TNBC and BCP vs. luminal A).

Cox regression models were also used to examine the predictive significance of the markers and the clustering schemes using interaction tests with hormonal therapy (yes $v s$. no) and radiation therapy (yes $v s$. no).

\begin{tabular}{|c|c|c|}
\hline Unknown & 45 & 5.4 \\
\hline Characteristic & & \\
\hline \multicolumn{3}{|c|}{ Ki67 protein expression, n (\%) } \\
\hline Low $(<20 \%)$ & 336 & 40.6 \\
\hline High $(\geq 20 \%)$ & 408 & 49.3 \\
\hline Unknown & 83 & 10.0 \\
\hline \multicolumn{3}{|c|}{ EGFR protein expression, $\mathrm{n}(\%)$} \\
\hline Positive & 118 & 14.3 \\
\hline Negative & 637 & 77.0 \\
\hline Unknown & 72 & 8.7 \\
\hline \multicolumn{3}{|c|}{ CK5 protein expression, $\mathrm{n}(\%)$} \\
\hline Positive & 81 & 9.8 \\
\hline Negative & 672 & 81.3 \\
\hline Unknown & 74 & 8.9 \\
\hline \multicolumn{3}{|l|}{ Subtype, n (\%) } \\
\hline Luminal A & 278 & 33.6 \\
\hline Luminal B & 215 & 26.0 \\
\hline Luminal-HER2 & 99 & 12.0 \\
\hline HER2-enriched & 77 & 9.4 \\
\hline TNBC & 94 & 11.4 \\
\hline $\mathrm{BCP}$ & 70 & 8.5 \\
\hline Unknown & 64 & 7.8 \\
\hline \multicolumn{3}{|c|}{ Chemotherapy, n (\%) } \\
\hline Yes & 625 & 75.6 \\
\hline No & 196 & 23.8 \\
\hline Unknown & 6 & 0.8 \\
\hline \multicolumn{3}{|c|}{ Radiotherapy, n (\%) } \\
\hline Yes & 601 & 72.6 \\
\hline No & 192 & 23.3 \\
\hline Unknown & 34 & 4.2 \\
\hline
\end{tabular}

N, Number; TNBC, Triple-negative breast cancer: estrogen receptor (ER)-negative, progesterone receptor $(\mathrm{PgR})$-negative, epidermal growth factor receptor 2 (HER2)-negative; BCP, basal core phenotype: TNBC, CK5-positive and/or EGFR-positive; Luminal A: ER-positive and/or PgR-positive, HER2-negative, Ki67low; Luminal B: ER-positive and/or PgR-positive, HER2-negative, Ki67high; Luminal-HER2: ER-positive and/or PgR-positive, HER2-positive; HER2-enriched: ER-negative, PgR-negative, HER2-positive.

Chi-square tests were performed to assess possible associations of the markers and clustering schemes with clinicopathological factors, as well as the associations of the markers with each other. All univariate tests were two-sided and significance level was set at $5 \%$, while in multivariate analyses, significance was determined at the level of $15 \%$.

No adjustment for multiple comparisons was performed. Results of this study are presented according to reporting recommendations for tumor marker prognostic studies (17). This study is prospectiveretrospective as described by Simon et al. (36). The statistical analysis was performed using SAS software (SAS for Windows, version 9.3; SAS Institute Inc., Cary, NC, USA).

\section{Results}

Basic patient and tumor characteristics characteristics are presented in Table I. Categorical variables are presented as frequencies with corresponding percentages, while the 
Table II. Protein expression of the markers under investigation.

\begin{tabular}{|c|c|c|}
\hline & $\mathrm{N}$ & $\%$ \\
\hline \multicolumn{3}{|l|}{ Nuclear RB } \\
\hline Absent (score 0) & 245 & 29.6 \\
\hline Positive (score 1, 2, 3) & 428 & 51.8 \\
\hline Unknown & 154 & 18.6 \\
\hline \multicolumn{3}{|l|}{ Nuclear pRB } \\
\hline Low $(<25 \%)$ & 333 & 40.3 \\
\hline High $(\geq 25 \%)$ & 315 & 38.1 \\
\hline Unknown & 179 & 21.6 \\
\hline \multicolumn{3}{|l|}{ RB pathway function } \\
\hline Altered/disrupted & 470 & 56.8 \\
\hline Normal & 236 & 28.5 \\
\hline Unknown & 121 & 14.6 \\
\hline \multicolumn{3}{|l|}{ Cytoplasmic p16 } \\
\hline Low $(<25 \%)$ & 609 & 73.6 \\
\hline High $(\geq 25 \%)$ & 109 & 13.2 \\
\hline Unknown & 109 & 13.2 \\
\hline \multicolumn{3}{|l|}{ Nuclear p16 } \\
\hline Low $(<25 \%)$ & 652 & 78.8 \\
\hline High $(\geq 25 \%)$ & 66 & 8.0 \\
\hline Unknown & 109 & 13.2 \\
\hline \multicolumn{3}{|l|}{ Nuclear cyclin D1 } \\
\hline Absent (score 0) & 164 & 19.8 \\
\hline Low (score 1) & 75 & 9.1 \\
\hline Intermediate (score 2) & 215 & 26.0 \\
\hline Strong (score 3 ) & 291 & 35.2 \\
\hline Unknown & 82 & 9.9 \\
\hline \multicolumn{3}{|l|}{ Nuclear p53 } \\
\hline Low $(<10 \%)$ & 415 & 50.2 \\
\hline High $(\geq 10 \%)$ & 325 & 39.3 \\
\hline Unknown & 87 & 10.5 \\
\hline
\end{tabular}

N, Number; RB, retinoblastoma; pRB, phosphorylated RB.

median and corresponding range are presented for continuous variables. In total, 827 patients with a measurement for at least one of the markers of interest were included in the analysis. The median age at diagnosis was 53.5 years. Fiftysix percent of the cases were postmenopausal, while the majority of the patients were diagnosed with tumors larger than $2 \mathrm{~cm}$. The tumors were ER/PgR-positive in $72.0 \%$ of cases and HER2-negative in $82.4 \%$ of the study population.

Median follow-up for the patients included in this study was 114.3 months (range=0.1-161.2 months), while median DFS and OS were not yet reached. By the last date of follow-up, $283(34.2 \%)$ of the patients had experienced a relapse, while 220 patients $(26.6 \%)$ had died.

Altered RB pathway was associated with high $\mathrm{pRB}$ $(p<0.001)$, while absence of RB was found to be associated with strong cyclin D1 protein expression and low pRB expression ( $p=0.003$ and $p=0.015$, respectively). In addition, low expression of $\mathrm{pRB}$ was found to be associated with low p53 expression $(p=0.040)$. Low p16 nuclear expression was
Table III. Expression of the markers of interest in the clustering schemes.

\begin{tabular}{lcccc}
\hline Clusters & $\mathrm{pRB}$ & $\mathrm{p} 16$ & $\mathrm{p} 53$ & Cyclin D1 \\
\hline Initial Scheme & $\uparrow$ & & & \\
1 & $\uparrow$ & $\downarrow$ & $\downarrow$ & $\downarrow$ \\
2 & $\uparrow$ & $\downarrow$ & $\downarrow$ & $\uparrow$ \\
3 & $\downarrow$ & $\downarrow$ & $\downarrow$ & $\downarrow$ \\
4 & $\downarrow$ & $\downarrow$ & $\downarrow$ & $\uparrow$ \\
5 & - & $\downarrow$ & $\uparrow$ & $\uparrow$ \\
6 & - & $\downarrow$ & $\uparrow$ & $\downarrow$ \\
7 & - & $\uparrow$ & - & $\downarrow$ \\
Grouped Scheme & & & & \\
1 & $\uparrow$ & $\downarrow$ & $\downarrow$ & $\downarrow$ \\
2,4 & - & $\downarrow$ & $\downarrow$ & $\uparrow$ \\
$3,5,6,7$ & $\downarrow$ & $\downarrow$ & - & $\downarrow$ \\
\hline
\end{tabular}

pRB: phosphorylated retinoblastoma. $\uparrow$ : high expression; $\downarrow$ : low expression; -: neither.

found to be associated with strong expression of cyclin D1, low p16 cytoplasmic expression and low expression of p53 $(p=0.003, p<0.001$ and $p=0.016$, respectively). No other significant associations were observed between the markers. The frequencies of protein expression of the markers under investigation are listed in Table II.

Absence of RB was associated with the triple-negative breast cancer (TNBC) and basal core phenotype (BCP) subtypes $(p<0.001$ and $p=0.002$, respectively), while low expression of $\mathrm{pRB}$ was associated with postmenopausal status $(p=0.026)$ and high histological grade $(p=0.027)$. Altered RB pathway was associated with the luminal A subtype $(p=0.037)$. Low 16 nuclear expression was found to be significantly associated with the invasive ductal histological type and with hormonal therapy ( $p=0.032$ and $p<0.001$, respectively). Low p16 nuclear and cytoplasmic protein expression was associated with positive ER/PgR status ( $p=0.007$ and $p=0.027$, respectively), while low cytoplasmic expression of p16 was associated with hormonal therapy and luminal A and B subtypes $(p<0.001$ and $p=0.045$, respectively).

Prognostic significance of individual markers. None of the markers under investigation reached any significance in terms of DFS in the univariate analysis. In terms of OS, p16 nuclear protein expression was the only significant marker for OS, with patients with low expression of nuclear p16 presenting lower risk for death [hazard ratio $(\mathrm{HR})=0.63,95 \%$ confidence interval $(\mathrm{CI})=0.41-0.97$, Wald's $p=0.039]$. In multivariate analysis adjusting for several clinicopathological parameters, low p16 nuclear expression retained its significance for OS (HR=0.66, 95\% CI=0.41-1.05, Wald's $p=0.083)$. 
Univariate analysis for the markers of interest was also performed in the subgroups of patients with TNBC and BCP patients, as well as in patients with luminal B tumors. However, none of the examined markers showed any prognostic significance for DFS or OS in any of these population subgroups.

Predictive significance of individual markers. None of the markers of interest were predictive for benefit from hormonal therapy either for DFS or OS. Similarly, none of the examined markers showed any significance for benefit from radiation therapy in terms of DFS or OS.

Clustering. In order to further evaluate possible prognostic significance of the retinoblastoma proteins unsupervised hierarchical clustering analysis was performed for the markers of interest combined with cyclin D1 and p53. RB was excluded from the clustering analysis due to its poor efficiency in identifying distinct groups (clusters). As for p16, only nuclear p16 protein expression was included in the clustering analysis, since nuclear expression is thought to more accurately reflect p16 function.

Clustering analysis revealed seven clusters, using pRB, nuclear p16, cyclin D1 and p53 protein expression (Figure 4). Cluster 1 represented patients with high expression of pRB, while cluster 2 and cluster 4 those with high expression of cyclin D1 and low expression of p16 nuclear and p53. The seven clusters derived from the initial clustering scheme were then grouped based on similar expression of the markers. The expression of the markers (high expression, low expression or neither) for each cluster in the initial clustering scheme, as well as in the grouped scheme, is presented in Table III.

Statistically significant associations were observed between the grouped scheme and several clinicopathological parameters. Specifically, cluster 1 was found to be significantly associated with younger age $(p=0.023)$, histological grade I-II $(p=0.001)$ and premenopausal status $(p=0.011)$. Grouped cluster 2, 4 was associated with hormonal therapy $(p<0.001)$, while grouped cluster 3, 5, 6, 7 with basal core phenotype $(p<0.001)$ and high Ki67 protein expression $(p=0.038)$.

In the univariate analysis, the initial clustering scheme did not reach any significance for DFS and OS (overall $p=0.24$ and $p=0.41$, respectively), while the grouped scheme showed a statistically significant difference for DFS (overall Wald's $p=0.034$ ) with a trend for OS (overall $p=0.080$ ). More specifically, cluster 1 was found to perform significantly better compared to the grouped cluster 3, 5, 6, 7 in terms of DFS (HR=0.48, 95\% CI=0.26-0.87, Wald's $p=0.015)$, while a trend was seen for OS $(\mathrm{HR}=0.55,95 \% \mathrm{CI}=0.29-1.05$, $p=0.072$ ). Kaplan-Meier curves for the grouped scheme with respect to DFS and OS are presented in Figure 5.
Since the initial clustering scheme did not reach any significance for DFS and OS in the univariate analysis, multivariate analysis was performed only for the grouped scheme. Adjusting for the clinicopathological characteristics described in the statistical analysis section, the grouped scheme retained its significance only in terms of DFS (overall Wald's $p=0.036$ ), with cluster 1 performing better compared to the grouped cluster 3, 5, 6, 7 (HR=0.48, 95\% $\mathrm{CI}=0.26-0.87$, Wald's $p=0.015$ ).

With regard to predictive value, the grouped scheme was not predictive for benefit from hormonal therapy (DFS interaction $p=0.34$ and OS interaction $p=0.29$ ) nor radiation therapy (DFS interaction $p=0.33$ and OS interaction $p=0.39$ ).

\section{Discussion}

In the present study, we sought to determine the IHC expression of RB, pRB and p16 in archived samples from a large phase III randomized adjuvant trial, in patients with breast cancer treated with adjuvant taxane-based chemotherapy and relate our results to several clinicopathological parameters, as well as to the clinical outcome of the patients.

In our study, we did not find significant associations of $\mathrm{RB}$ and $\mathrm{pRB}$ with DFS and OS. Absence of the RB protein was found to be associated with the TNBC and BCP subtypes, which is in aggrement with other investigators (37, 38 ), nevertheless we did not find any association with DFS or OS as they did $(37,38)$. Furthermore, we found low expression of $\mathrm{pRB}$ to be associated with tumors of high histological grade, which are highly proliferative, as indicated by increased protein expression of Ki67. Such an association of high histological grade with low $\mathrm{pRB}$ protein expression has been described by other investigators (39, 40). Lastly, altered or disrupted RB pathway function was found to be associated with high pRB expression, indicating that, at least in our cohort, hyperphosphorylation of the RB protein might more accurately reflect a disrupted $\mathrm{RB}$ pathway, as opposed to absence of RB.

Nuclear p16 protein expression was the only significant prognostic marker in terms of OS, with patients with low expression presenting lower risk for death, while no significance was observed for DFS. This was to be expected, since we observed low nuclear p16 protein expression in ER/PgR-positive tumors, which have favorable prognostic features. Although these findings seem to be different from the results reported by some investigators $(41,42)$, other studies showed that p16 protein overexpression is more frequently seen in BCP tumors compared to non-basal ones $(29,43)$. It appears, therefore, that the down-regulation of nuclear p16 observed in our study is a marker of good prognosis, which is in agreement with other investigators highlighting nuclear p16 overexpression as being a marker of poor prognosis $(43,44)$. 
In order to further evaluate possible prognostic significance of the retinoblastoma proteins clustered analysis of our data was performed. Clustering analysis revealed 7 clusters, using pRB, p16 nuclear, cyclin D1 and p53 protein expression. This initial clustering scheme did not reach any significance for DFS or OS, therefore the seven clusters were grouped based on similar expression of the markers, with cluster 1 found to perform better compared to the grouped cluster 3, 5, 6, 7 in terms of DFS, both in univariate and multivariate analyses. The increased DFS observed in cluster 1 was found to be associated with high values of $\mathrm{pRB}$ and concomitantly low values of p16, p53 and cyclin D1. Tumors with the above phenotype were of low grade and ER/PgR-positive, tumor characteristics that are associated with good prognosis. On the other hand, grouped cluster 3, 5, 6, 7 had tumors with low values of all four factors and performed worst with regard to the prognosis of the patients. As expected, the latter tumors were BCP with high expression of Ki67.

When considering our results, it is evident that on an IHC basis, the only finding that differentiates clusters with good from those with poor prognosis is the expression of $\mathrm{pRB}$. The hyperphosphorylation of RB, as shown by the high $\mathrm{pRB}$ values observed for cluster 1 , characterized a group of patients with tumors with better outcome. This is a paradoxical finding, since normally, hyperphosphorylated RB would lead to uncontrolled cell proliferation and tumor progression $(10,45,46)$. Yet recent data have demonstrated that tumors with RB loss, a condition that exerts the same effect as activated $\mathrm{pRB}$, are more apt to respond to optimized chemotherapeutic strategies $(37,45)$. Therefore, one could speculate that the better outcome observed in patients with tumors characterized by high levels of pRB could be primarily related to improved response to therapy rather than to direct effects of the proteins involved in the specific pathway. However, it should be noted that in our study, an altered or disrupted RB pathway was significantly associated with the luminal A subtype. Patients with luminal A breast cancer have the best prognosis compared to all other subtypes, especially in the pre-trastuzumab era, during which HER2-positive patients were not supposed to be treated with trastuzumab or other anti-HER2 agents in the adjuvant setting, as was the case in our trial.

Taken together, the results of our study, on a large cohort of patients with breast cancer treated with taxane-based chemotherapy, lead us to the conclusion that the role of the $\mathrm{RB}$ pathway and its downstream regulators in breast cancer progression is multifaceted. The disruption of the RB pathway, due either to loss of RB protein (37) or to the hyperphosphorylation of RB protein, appears to increase the chemosensitivity of our patients. Therefore, the interaction between the functional status of the different genes that are involved in the RB signaling pathway and their effect on the responsiveness of neoplastic cells to chemotherapeutic agents should be taken into account. The IHC expression of related factors does not necessarily reflect the complex molecular alterations that drive a gene's functional diversity and cellcycle regulation. Nevertheless, our data indicate a pivotal role of the RB pathway in the response to chemotherapeutic agents in this cohort of patients with breast cancer. It is possible that the p53-mediated sensitivity of breast cancer cells to chemotherapy could be driven by $\mathrm{pRB}$.

It is clear that additional studies should be carried out in order to understand the role of a disrupted RB pathway in the development of breast cancer. Moreover, it is essential to further investigate the role of the pRB and p16 proteins in response to chemotherapy in order to identify novel targets for therapeutic interventions. Our results indicate that the use of agents that enhance RB phosphorylation might possibly increase the chemosensitivity of breast cancer cells. However, our findings should merely be viewed as hypothesis-generating until they are confirmed in prospective validation cohorts.

\section{Acknowledgements}

The Authors are indebted to all patients and their families for their trust and participation in the Hellenic Cooperative Oncology Group trials and for the provision of biological material for research purposes.

The Authors thank Christos Valavanis (MD, Ph.D.) for his valued help during scheduling of the assays and Thomas Karinos for technical assistance.

\section{References}

1 Prat A, Pineda E, Adamo B, Galvan P, Fernandez A, Gaba L, Diez M, Viladot M, Arance A and Munoz M: Clinical implications of the intrinsic molecular subtypes of breast cancer. Breast 24(Suppl 2): S26-35, 2015.

2 Gogas H, Dafni U, Karina M, Papadimitriou C, Batistatou A, Bobos M, Kalofonos HP, Eleftheraki AG, Timotheadou E, Bafaloukos D, Christodoulou C, Markopoulos C, Briasoulis E, Papakostas P, Samantas E, Kosmidis P, Stathopoulos GP, Karanikiotis C, Pectasides D, Dimopoulos MA and Fountzilas G: Postoperative dose-dense sequential versus concomitant administration of epirubicin and paclitaxel in patients with nodepositive breast cancer: 5-year results of the Hellenic Cooperative Oncology Group HE 10/00 phase III trial. Breast Cancer Res Treat 132(2): 609-619, 2012.

3 Viedma-Rodriguez R, Baiza-Gutman L, Salamanca-Gomez F, Diaz-Zaragoza M, Martinez-Hernandez G, Ruiz Esparza-Garrido R, Velazquez-Flores MA and Arenas-Aranda D: Mechanisms associated with resistance to tamoxifen in estrogen receptorpositive breast cancer (review). Oncol Rep 32(1): 3-15, 2014.

4 Cardoso F, Ross JS, Picart MJ, Sotiriou C and Durbecq V: Targeting the ubiquitin-proteasome pathway in breast cancer. Clin Breast Cancer 5(2): 148-157, 2004.

5 Andre F, Dieci MV, Dubsky P, Sotiriou C, Curigliano G, Denkert $\mathrm{C}$ and Loi S: Molecular pathways: Involvement of immune pathways in the therapeutic response and outcome in breast cancer. Clin Cancer Res 19(1): 28-33, 2013. 
6 Vousden KH and Lu X: Live or let die: The cell's response to p53. Nat Rev Cancer 2(8): 594-604, 2002.

7 Johnstone RW, Ruefli AA and Lowe SW: Apoptosis: A link between cancer genetics and chemotherapy. Cell 108(2): 153164, 2002.

8 Ablain J, Poirot B, Esnault C, Lehmann-Che J and de The H: $\mathrm{P} 53$ as an effector or inhibitor of therapy response. Cold Spring Harb Perspect Med 6(1): a026260, 2015.

9 Derenzini M, Brighenti E, Donati G, Vici M, Ceccarelli C, Santini D, Taffurelli M, Montanaro L and Trere D: The p53mediated sensitivity of cancer cells to chemotherapeutic agents is conditioned by the status of the retinoblastoma protein. $\mathrm{J}$ Pathol 219(3): 373-382, 2009.

10 Herschkowitz JI, He X, Fan C and Perou CM: The functional loss of the retinoblastoma tumour suppressor is a common event in basal-like and luminal b breast carcinomas. Breast Cancer Res 10(5): R75, 2008

11 Lee EY, To H, Shew JY, Bookstein R, Scully P and Lee WH: Inactivation of the retinoblastoma susceptibility gene in human breast cancers. Science 241(4862): 218-221, 1988.

12 Romagosa C, Simonetti S, Lopez-Vicente L, Mazo A, Lleonart ME, Castellvi J and Ramon y Cajal S: P16(ink4a) overexpression in cancer: A tumor-suppressor gene associated with senescence and high-grade tumors. Oncogene 30(18): 2087-2097, 2011.

13 Fountzilas G, Dafni U, Gogas H, Linardou H, Kalofonos HP, Briasoulis E, Pectasides D, Samantas E, Bafaloukos D, Stathopoulos GP, Karina M, Papadimitriou C, Skarlos D, Pisanidis N, Papakostas P, Markopoulos C, Tzorakoeleftherakis E, Dimitrakakis K, Makrantonakis P, Xiros N, Polichronis A, Varthalitis I, Karanikiotis C, Dimopoulos AM and Hellenic Cooperative Oncology G: Postoperative dose-dense sequential chemotherapy with epirubicin, paclitaxel and CMF in patients with high-risk breast cancer: Safety analysis of the Hellenic Cooperative Oncology Group randomized phase III trial HE 10/00. Ann Oncol 19(5): 853-860, 2008.

14 Goldhirsch A, Wood WC, Gelber RD, Coates AS, Thürlimann B and Senn HJ: Progress and promise: Highlights of the International Expert Consensus on the Primary Therapy of Early Breast Cancer 2007. Ann Oncol 18(7): 1133-1144, 2007.

15 Razis E, Bobos M, Kotoula V, Eleftheraki AG, Kalofonos HP, Pavlakis K, Papakostas P, Aravantinos G, Rigakos G, Efstratiou I, Petraki K, Bafaloukos D, Kostopoulos I, Pectasides D, Kalogeras KT, Skarlos D and Fountzilas G: Evaluation of the association of PIK3CA mutations and PTEN loss with efficacy of trastuzumab therapy in metastatic breast cancer. Breast Cancer Research and Treatment 128(2): 447-456, 2011.

16 Fountzilas G, Dafni U, Bobos M, Batistatou A, Kotoula V, Trihia H, Malamou-Mitsi V, Miliaras S, Chrisafi S, Papadopoulos S, Sotiropoulou M, Filippidis T, Gogas H, Koletsa T, Bafaloukos D, Televantou D, Kalogeras KT, Pectasides D, Skarlos DV, Koutras A and Dimopoulos MA: Differential response of immunohistochemically defined breast cancer subtypes to anthracycline-based adjuvant chemotherapy with or without paclitaxel. PLoS ONE 7(6): e37946, 2012.

17 McShane LM, Altman DG, Sauerbrei W, Taube SE, Gion M and Clark GM: Reporting recommendations for tumour marker prognostic studies (remark). British Journal of Cancer 93(4): 387-391, 2005.

18 Kononen J, Bubendorf L, Kallionimeni A, Barlund M, Schraml P, Leighton S, Torhorst J, Mihatsch MJ, Sauter G and Kallionimeni
O-P: Tissue microarrays for high-throughput molecular profiling of tumor specimens. Nat Med 4(7): 844-847, 1998.

19 Skacel M, Skilton B, Pettay JD and Tubbs RR: Tissue microarrays: A powerful tool for high-throughput analysis of clinical specimens: A review of the method with validation data. Appl Immunohistochem Mol Morphol 10(1): 1-6, 2002.

20 Fountzilas G, Kourea HP, Bobos M, Televantou D, Kotoula V, Papadimitriou C, Papazisis KT, Timotheadou E, Efstratiou I, Koutras A, Pentheroudakis G, Christodoulou C, Aravantinos G, Miliaras D, Petraki K, Papandreou CN, Papakostas P, Bafaloukos D, Repana D, Razis E, Pectasides D and Dimopoulos AM: Paclitaxel and bevacizumab as first line combined treatment in patients with metastatic breast cancer: The Hellenic Cooperative Oncology Group experience with biological marker evaluation. Anticancer Res 31(9): 30073018, 2011.

21 Psyrri A, Kalogeras KT, Kronenwett R, Wirtz RM, Batistatou A, Bournakis E, Timotheadou E, Gogas H, Aravantinos G, Christodoulou C, Makatsoris T, Linardou H, Pectasides D, Pavlidis N, Economopoulos T and Fountzilas G: Prognostic significance of UBE2C mRNA expression in high-risk early breast cancer. A Hellenic Cooperative Oncology Group (HECOG) study. Ann Oncol 23(6): 1422-1427, 2011.

22 Fountzilas G, Dafni U, Bobos M, Kotoula V, Batistatou A, Xanthakis I, Papadimitriou C, Kostopoulos I, Koletsa T, Tsolaki E, Televantou D, Timotheadou E, Koutras A, Klouvas G, Samantas E, Pisanidis N, Karanikiotis C, Sfakianaki I, Pavlidis N, Gogas H, Linardou H, Kalogeras KT, Pectasides D and Dimopoulos MA: Evaluation of the prognostic role of centromere 17 gain and HER2/topoisomerase ii alpha gene status and protein expression in patients with breast cancer treated with anthracycline-containing adjuvant chemotherapy: Pooled analysis of two Hellenic Cooperative Oncology Group (HECOG) phase III trials. BMC Cancer 13(1): 163, 2013.

23 Stavridi F, Kalogeras KT, Pliarchopoulou K, Wirtz RM, Alexopoulou Z, Zagouri F, Veltrup E, Timotheadou E, Gogas H, Koutras A, Lazaridis G, Christodoulou C, Pentheroudakis G, Laskarakis A, Arapantoni-Dadioti P, Batistatou A, Sotiropoulou M, Aravantinos G, Papakostas P, Kosmidis P, Pectasides D and Fountzilas G: Comparison of the ability of different clinical treatment scores to estimate prognosis in high-risk early breast cancer patients: A Hellenic Cooperative Oncology Group study. PLoS ONE 11(10): e0164013, 2016.

24 Psyrri A, Kalogeras KT, Wirtz RM, Kouvatseas G, Karayannopoulou G, Goussia A, Zagouri F, Veltrup E, Timotheadou E, Gogas H, Koutras A, Lazaridis G, Christodoulou C, Pentheroudakis G, Economopoulou P, Laskarakis A, Arapantoni-Dadioti P, Batistatou A, Sotiropoulou M, Aravantinos G, Papakostas P, Kosmidis P, Pectasides D and Fountzilas G: Association of osteopontin with specific prognostic factors and survival in adjuvant breast cancer trials of the Hellenic Cooperative Oncology Group. J Transl Med 15(1): 30, 2017.

25 Hammond ME, Hayes DF, Dowsett M, Allred DC, Hagerty KL, Badve S, Fitzgibbons PL, Francis G, Goldstein NS, Hayes M, Hicks DG, Lester S, Love R, Mangu PB, McShane L, Miller K, Osborne CK, Paik S, Perlmutter J, Rhodes A, Sasano H, Schwartz JN, Sweep FC, Taube S, Torlakovic EE, Valenstein P, Viale G, Visscher D, Wheeler T, Williams RB, Wittliff JL and Wolff AC: American Society of Clinical Oncology/College of American Pathologists guideline recommendations for immunohistochemical 
testing of estrogen and progesterone receptors in breast cancer. J Clin Oncol 28(16): 2784-2795, 2010.

26 Wolff AC, Hammond ME, Schwartz JN, Hagerty KL, Allred DC, Cote RJ, Dowsett M, Fitzgibbons PL, Hanna WM, Langer A, McShane LM, Paik S, Pegram MD, Perez EA, Press MF, Rhodes A, Sturgeon C, Taube SE, Tubbs R, Vance GH, van de Vijver M, Wheeler TM and Hayes DF: American Society of Clinical Oncology/College of American Pathologists guideline recommendations for human epidermal growth factor receptor 2 testing in breast cancer. J Clin Oncol 25(1): 118-145, 2007.

27 Cheang MC, Chia SK, Voduc D, Gao D, Leung S, Snider J, Watson M, Davies S, Bernard PS, Parker JS, Perou CM, Ellis MJ and Nielsen TO: Ki67 index, HER2 status, and prognosis of patients with luminal B breast cancer. J Natl Cancer Inst 101(10): 736-750, 2009.

28 Diallo-Danebrock R, Ting E, Gluz O, Herr A, Mohrmann S, Geddert H, Rody A, Schaefer KL, Baldus SE, Hartmann A, Wild PJ, Burson M, Gabbert HE, Nitz U and Poremba C: Protein expression profiling in high-risk breast cancer patients treated with high-dose or conventional dose-dense chemotherapy. Clin Cancer Res 13(2 Pt 1): 488-497, 2007.

29 Shan M, Zhang X, Liu X, Qin Y, Liu T, Liu Y, Wang J, Zhong Z, Zhang Y, Geng J and Pang D: P16 and p53 play distinct roles in different subtypes of breast cancer. PLoS One 8(10): e76408, 2013.

30 Lehn S, Tobin NP, Berglund P, Nilsson K, Sims AH, Jirstrom K, Harkonen P, Lamb R and Landberg G: Down-regulation of the oncogene cyclin $\mathrm{d} 1$ increases migratory capacity in breast cancer and is linked to unfavorable prognostic features. Am J Pathol 177(6): 2886-2897, 2010.

31 Bartlett JM, Munro AF, Dunn JA, McConkey C, Jordan S, Twelves CJ, Cameron DA, Thomas J, Campbell FM, Rea DW, Provenzano E, Caldas C, Pharoah P, Hiller L, Earl H and Poole CJ: Predictive markers of anthracycline benefit: A prospectively planned analysis of the UK National Epirubicin Adjuvant Trial (NEAT/BR9601). Lancet Oncol 11(3): 266-274, 2010.

32 Press MF, Sauter G, Buyse M, Bernstein L, Guzman R, Santiago A, Villalobos IE, Eiermann W, Pienkowski T, Martin M, Robert N, Crown J, Bee V, Taupin H, Flom KJ, Tabah-Fisch I, Pauletti G, Lindsay M-A, Riva A and Slamon DJ: Alteration of topoisomerase II-alpha gene in human breast cancer: Association with responsiveness to anthracycline-based chemotherapy. J Clin Oncol 29(7): 859-867, 2011.

33 Vanden Bempt I, Van Loo P, Drijkoningen M, Neven P, Smeets A, Christiaens MR, Paridaens $\mathrm{R}$ and De Wolf-Peeters C: Polysomy 17 in breast cancer: Clinicopathologic significance and impact on HER-2 testing. J Clin Oncol 26(30): 4869-4874, 2008.

34 Sauter G, Lee J, Bartlett JM, Slamon DJ and Press MF: Guidelines for human epidermal growth factor receptor 2 testing: Biologic and methodologic considerations. J Clin Oncol 27(8): 1323-1333, 2009.

35 Hudis CA, Barlow WE, Costantino JP, Gray RJ, Pritchard KI, Chapman JA, Sparano JA, Hunsberger S, Enos RA, Gelber RD and Zujewski JA: Proposal for standardized definitions for efficacy end points in adjuvant breast cancer trials: The steep system. J Clin Oncol 25(15): 2127-2132, 2007.
36 Simon RM, Paik S and Hayes DF: Use of archived specimens in evaluation of prognostic and predictive biomarkers. J Natl Cancer Inst 101(21): 1446-1452, 2009.

37 Trere D, Brighenti E, Donati G, Ceccarelli C, Santini D, Taffurelli M, Montanaro L and Derenzini M: High prevalence of retinoblastoma protein loss in triple-negative breast cancers and its association with a good prognosis in patients treated with adjuvant chemotherapy. Ann Oncol 20(11): 1818-1823, 2009.

38 Derenzini M, Donati G, Mazzini G, Montanaro L, Vici M, Ceccarelli C, Santini D, Taffurelli M and Trere D: Loss of retinoblastoma tumor suppressor protein makes human breast cancer cells more sensitive to antimetabolite exposure. Clin Cancer Res 14(7): 2199-2209, 2008.

39 Ceccarelli C, Santini D, Chieco P, Taffurelli M, Gamberini M, Pileri SA and Marrano D: Retinoblastoma (RB1) gene product expression in breast carcinoma. Correlation with Ki-67 growth fraction and biopathological profile. J Clin Pathol 51(11): 818$824,1998$.

40 Geradts $\mathrm{J}$ and Wilson PA: High frequency of aberrant p16(INK4A) expression in human breast cancer. Am J Pathol 149(1): 15-20, 1996.

41 Shin E, Jung WH and Koo JS: Expression of p16 and pRB in invasive breast cancer. Int J Clin Exp Pathol 8(7): 8209-8217, 2015.

42 Arima Y, Hayashi N, Hayashi H, Sasaki M, Kai K, Sugihara E, Abe E, Yoshida A, Mikami S, Nakamura S and Saya H: Loss of p16 expression is associated with the stem cell characteristics of surface markers and therapeutic resistance in estrogen receptornegative breast cancer. Int J Cancer 130(11): 2568-2579, 2012.

43 Abou-Bakr AA and Eldweny HI: P16 expression correlates with basal-like triple-negative breast carcinoma. Ecancermedicalscience 7: 317, 2013.

44 Milde-Langosch K, Bamberger AM, Rieck G, Kelp B and Loning T: Overexpression of the p16 cell cycle inhibitor in breast cancer is associated with a more malignant phenotype. Breast Cancer Res Treat 67(1): 61-70, 2001.

45 Witkiewicz AK, Ertel A, McFalls J, Valsecchi ME, Schwartz G and Knudsen ES: RB-pathway disruption is associated with improved response to neoadjuvant chemotherapy in breast cancer. Clin Cancer Res 18(18): 5110-5122, 2012.

46 Peurala E, Koivunen P, Haapasaari KM, Bloigu R and JukkolaVuorinen A: The prognostic significance and value of cyclin D1, CDK4 and p16 in human breast cancer. Breast Cancer Res 15(1): R5, 2013
Received April 11, 2017

Revised April 28, 2017

Accepted May 2, 2017 